\title{
Cultural struggles in the lusofonia arena: Portuguese-speaking migrant musicians in Lisbon
}

\author{
Bart P. Vanspauwen \\ Instituto de Etnomusicologia, New University of Lisbon, Portugal
}

\begin{abstract}
Approaching music as a point of social connection in the post-colonial city of Lisbon, where cultural entrepreneurs deploy the political concept of lusofonia, this study examines the ways in which local migrant musicians from Portuguese-speaking African countries (PALOP), as well as Brazil and East Timor, position themselves in this context. In general, the study shows that there is a lack of recognition of the contribution they make to the expressive culture of the Portuguese capital, and this is related to national preconceptions. Surprisingly, despite several existing counter-discourses regarding lusofonia, all interviewed musicians do see some future relevance in this concept. They appeal to both supranational institutions and national governments, asking for structural support in order to promote and disseminate all the expressive culture of Portuguesespeaking African countries, indicating that the contribution of migrant musicians from these countries should be considered as an integral part of Portugal's cultural expression and heritage.
\end{abstract}

Key words: Lusofonia, Portugal, migrant musicians, cultural policy, postcolonialism

O Mar foi ontem o que o idioma pode ser hoje, basta vencer algunsadamastores ${ }^{1}$ Mia Couto

\section{Introduction}

On 25 February 20II, TAP, the Portuguese national airline, offering more than 70 weekly flights to and from various Brazilian cities as well as a dozen others to the capitals of Cape Verde, Guinea-Bissau, Angola and Mozambique, put the video clip 'De Braços Abertos' ['With Arms Wide Open'], its new company anthem, on its YouTube channel. ${ }^{2}$ The clip features well-known and successful musicians from three lusophone [Portuguese-speaking] countries: Portuguese Mariza, Angolan Paulo Flores and Brazilian Roberta Sá, that jointly perform a song that profiles itself as "an 'anthem' towards the union

The sea was yesterday what language can be today, it suffices to overcome some mythical giants.

2 http://www.youtube.com/watch?v=Sivfiugqljo (Last consulted: October 6, 2012). 
of lusophone cultures". 'De Braços Abertos' "illustrates the proximity and complementarity between these 3 peoples that share language, culture and history" (ibid.). TAP's 'De Braços Abertos' is a telling mix of marketing and cultural politics. It also illustrates that in $201 \mathrm{I}$, some 15 years after the concept of lusofonia first came into vogue, its essence is still relevant.

For most organizers of contemporary music and culture events in Lisbon, ${ }^{4}$ the 2006 documentary Lusofonia: a (r)evolução (see below) seems to have been an important moment in the fostering of a collective experience of Lusophone musical cultures, often referred to by insiders as lusofonia. Music is a privileged perspective for understanding such experiences.

Approaching music as a point of social connection in a post-colonial city where cultural entrepreneurs deploy the political concept of lusofonia, this study examines the ways in which migrant musicians from Portuguese-speaking African countries (PALOP), as well as from Brazil and East Timor, that are living in Lisbon, position themselves in this context. This perspective is based on the work of ethnomusicologists and other social scientists that, in a global context of diaspora and transnationalism, understand that cultural systems may be articulated linguistically rather than geographically. ${ }^{5}$ This corresponds to the field of ethnomusicology, which aims to address popular music as a privileged site for the exploration of national identity and culture (Arenas 20ri:46).

What is the role of migrant musicians from Portuguese-speaking countries in constructing the concept of lusofonia? How do they judge this concept in a context of conflicting discourses in which Portugal's national music, fado, seems to be an enigmatic emblem of cultural tradition? Are racial issues or former colonial representations still influential?

The relevance of this project is multifold. Given the increasing importance of the Portuguese language on the global stage, as well as the influential call for a 'Lusophone musical identity' by the 2006 documentary Lusofonia: a (r)evolução, the performances and opinions of these musicians should be understood as important sites of socialization and negotiation that transcend national boundaries. In addition, post-colonial migrant communities in Europe, that have traditionally been overlooked or forgotten both in academia and in terms of institutional action, are now becoming more visible on national political and cultural agendas, implying a revision of their relationship to the reference values of the host society as well as their social incorporation and social participation. In the case of Portugal, which hosts a diversity of Lusophone migrant populations in its capital, it seems fruitful to reflect on what this entails with respect to a "Lusophone community" (also see Maciel 2010:207, 216). Beyond seeing these migrants as mere economic agents, whose performance at cultural and artistic levels has for a long time been underestimated, in-depth studies need to be carried out from a multidisciplinary perspective on several basic questions such as the role of music in the

3 All translations from Portuguese to English are my own.

4 With the denomination Lisbon, I refer to the Lisbon Metropolitan Area.

5 I am indebted to Prof. Dr. Koen Stroeken in elaborating this thought. 
construction and maintenance of identity in multicultural contexts, both on the historical and synchronic levels (Castelo-Branco 1997:4I, Maciel 2010:216).

For my master thesis research (2008-10) and subsequent doctoral thesis investigation (2010-2012) at Universidade Nova de Lisboa, I discursively analyzed how the notion of lusofonia and the action of governmental institutions and voluntary associations inform the creative work and identities of selected Portuguese-speaking migrant musicians from the PALOP, as well as Brazil and East Timor, through ethnographic interviews and participant-observation. In general, the results of this research indicate an interesting tension between, on the one hand, institutional actors who appear to be interested in framing perceptions of lusofonia in such a way that it becomes a cohesive idea binding together political, economic, linguistic or cultural elements, and on the other, the reality of voluntary associations and migrant musicians from Portuguese-speaking countries who evoke the concept to varying extent.

Although the term lusofonia is also used to express social, political and economic connections and activities, music and culture can offer an interesting prism of investigation that is both reflexive and generative. It is often through musical performances that ideas, emotions, beliefs, attitudes, experiences, and cultural identities are embodied. Therefore, music - examined as social process, as expressive behavior, and as cultural product - is an especially suitable domain for the study of processes engendered by cross-cultural encounters (Castelo-Branco 1997:32). Music is a social and hence discursive construction that can be better understood when viewed from the networks of exchange, sharing and cooperation established between the various agents interwoven in its production, diffusion and dissemination (cfr. Maciel 2010:303).

Below, a definition and critique of lusofonia is presented, followed by a brief sociocultural history of PALOP migrant musicians in Lisbon, which is in turn linked to the ethnography conducted in the field for the present study.

\section{Definition and critique}

To contextualize about the issue of lusofonia in the present-day context, a brief historical depiction of Portuguese colonialism is necessary. Portuguese presence overseas varied widely in its nature and length, as did the ensuing economic, political, social and cultural processes, which affected both the Portuguese and the peoples with whom they came into contact (Castelo-Branco I997:3I). The Portuguese discoveries - as the intensive maritime exploration by the Portuguese is also called - mapped the coasts of Africa, Asia and Brazil during the 15 th and 16 th centuries. Rio de Janeiro, in Brazil, was the Portuguese capital between 1808 and $182 \mathrm{I}$, initially in order to protect the royal family from the invasion of Napoleon Bonaparte. Lisbon regained its status as the capital of Portugal when Brazil declared its independence from Portugal in 1822 . The Carnation Revolution of 1974, effectively a bloodless left-wing military coup, installed democracy in Portugal. In 1975 , Portugal granted independence to its Overseas Provinces in Africa (Angola, Cape Verde, Guinea-Bissau, Mozambique and São Tomé and Príncipe). Nearly I million military personnel and citizens (Portuguese or of Portuguese descent) returned to Portugal as 
refugees (retornados). In the following decades, the newly-independent countries suffered from protracted civil wars - the Angolan Civil War (1975-2002) and Mozambican Civil War (1977-1992) - resulting in millions of deaths and refugees. Meanwhile, Brazil exited a period of military dictatorship in 1985 . In 1986, Portugal entered the European Economic Community. In I996, the Community of Portuguese-speaking Countries (CPLP, Comunidade de Países de Língua Portuguesa) was founded in Lisbon, including Angola, Brazil, Cape Verde, Guinea-Bissau, Mozambique, Portugal, and São Tomé and Príncipe. Portugal lost its final colonial possessions as recently as I999, when Macau was returned to China, and in 2002, when East Timor - that had been invaded and annexed by Indonesia in 1975 - became independent, joining the CPLP shortly thereafter. The specific effects of the above on migration will be discussed in part 3 .

Lusofonia is a relatively recent concept that has been increasingly common since the 1990s. It is grounded in a linguistic definition, but also designates a political, economic and cultural space. Although its historical roots can be found in Portuguese colonialism, the concept's contemporary meaning(s) originated in the Orthographic Agreement, gaining a new significance with the increased migration from the former Portuguese colonies, mainly from Africa to Lisbon, from 1974 on. The creation of CPLP - the Community of Portuguese-speaking Countries ${ }^{6}$ in 1996 , international events such as the 1998 World Exposition (Expo '98), the transnational music industry as well as the advent of the Internet (both information and social networks) have also contributed to the extension of the term lusofonia beyond a strictly linguistic scope.

Following on from that period, lusofonia has increasingly informed the international relations of Lisbon. Many governmental and municipal institutions, scholars, voluntary associations, cultural entrepreneurs, musicians and journalists evoke the concept explicitly in their objectives. CPLP, a crucial actor in the institutionalization of lusofonia, is based in Lisbon. Furthermore, governmental, economic, academic, juridical and sport institutions that involve other Portuguese-speaking countries or regions, take Lisbon as a point of reference and often use the concept of lusofonia. Lisbon's voluntary associations also evoke or illustrate the concept, as is exemplified by Associação Sons da Lusofonia (1996)7 and 'Lusofonias: Culturas em Comunidade' (2008) ${ }^{8}$ of Associação Etnia. Lisbon constitutes a privileged stage for encounters between Portuguese musicians, resident migrant musicians and musicians on tour from other CPLP-countries, as may become clear from the documentary Lusofonia, a (R)evolução.

CPLP reunites more than 223 million Portuguese speakers in 8 countries: Angola, Brazil, Cape Verde, Guinea-Bissau, Mozambique, Portugal, São Tomé and Príncipe and East Timor. A unique characteristic of CPLP is that its member states are linked by a common language and share cultural elements, which serve to create bridges between

6 http://www.cplp.org (Last consulted: October 6, 201 2).

7 http://www.sonsdalusofonia.com/SonsdaLusofonia/tabid/58/language/pt-PT/Default.aspx (Last consulted: October 6, 2012).

8 http://lusofonias 2008.blogspot.com (Last consulted: October 6, 2012). 
these countries that are geographically dispersed. ${ }^{9}$ In 2005, at a meeting in Luanda, CPLP chose May $5^{\text {th }}$ to globally commemorate the Dia da Cultura Lusófona. Since 2008, the Semana Cultural da CPLP ${ }^{10}$ has been held yearly on that date in Lisbon.

The Portuguese language thus is the foundational element on which the concept of lusofonia rests. It serves as a metaphor of unification. In this sense, lusofonia can be compared with francophonie. The Organisation Internationale de la Francophonie (IOF), ${ }^{\prime \prime}$ created in 1970 , incorporates 70 member states and governments, which account for a population of over 870 million people, including 200 million native French speakers. Cultural aspects are celebrated yearly on March 2oth during the Journée internationale de la Francophonie ${ }^{12}$ (since 1998). The IOF has also established permanent dialogue between the major international linguistic zones (the English, Portuguese, Spanish, and Arab-speaking zones).

Hence, the linguistic designator 'lusophone' must be relativized in view of the fact that Portuguese, even though it is the 'official' language, exists in national and regional spaces that are either bilingual or multilingual (cfr. Arenas 2005:np). In Angola, Portuguese coexists with other national languages; in countries such as Cape Verde, GuineaBissau and Mozambique other languages dominate-Creole or other local tongues; and in East Timor only a minority speaks Portuguese. Moreover, Mozambique is part of the Commonwealth and Senegalese (francophone) influence is present in São Tomé and Príncipe ${ }^{13}$ as well as in Guinea-Bissau. Goa, Galicia, Macau as well as Portuguese-speaking diaspora populations in cities around the globe offer yet another context-specific picture. ${ }^{14}$

In short, transnational alliances on the basis of language may have varying validity in these areas. Alternatively, the use of Portuguese is expanding in PALOP countries through national and international radio and television via satellite, through the print media, and by means of the school system, "as a vehicle for social mobility" (ibid.). Brazil remains the main propagator of the Portuguese language, with over I9o million speakers, and has the Museu da Língua Portuguesa' ${ }^{15}$ in São Paulo (inaugurated in March 2006). In addition, preconceptions regarding non-Portuguese accents persist, putting Brazil and the PALOP in an ambiguous position in relation to continental Portugal.

9 Cfr. introductory note of Migração e Políticas de Desenvolvimento no Quadro da CPLP. International seminar for the Gulbenkian Migration Forum, held June 2006 in Lisbon.

Io http://www.cplp.org/id-2215.aspx (Last consulted: October 6, 2012).

II http://www. francophonie.org (Last consulted: October 6, 2012).

12 http://2omars. francophonie.org (Last consulted: October 6, 2012).

13 French is also taught in schools, as the country is a member of Francophonie.

I4 In addition, Sanches (2004: 126-7) points to common traits between diasporic literatures written in different colonial languages, or between Guinea-Bissau and Guinea-Conakry, or Senegal, "which make of francophonie an important presence in Guinea-Bissau and Cape Verde and English an important medium in Mozambique, or Creole and French, English, Dutch, or Portuguese among Cape Verdians in the diaspora." She also refers to the mutual influences between Brazil and the PALOP, and the reception of African American writers and Negritude in Mozambique and Angola.

15 http://www.museudalinguaportuguesa.org.br. 
Language has never been a neutral instrument for mere communicative empirical use; it remains closely linked to ideological expressions, power relations and cultural options (Maciel 2010:252). The choice of the word 'luso'16 can easily be critiqued when viewed through the democratic, transnational lens of Arenas (20II), which argues that Portugal, even though it constitutes lusofonia's original linguistic matrix, must abandon claims of being the center and instead recognize as well as foster multipolarity. Martins (2006: 2337) in this sense conceives lusofonia as a new reticular geopolitical model: "it already is, because it started in a distant past, and has become heritage" (ibid.). According to Cristóvão (2005:652), "to use the word 'Luso', instead of 'Portuguese', is already a way of surpassing nationalism and to enter in the domain of the mythical and the symbolical."

Lusofonia seems to be a practical classification that is subordinated to diverse functions to produce desired social effects. Its strength in part arises from the fact that the figure of lusofonia is not that different from the social reality of the distinct national communities where this symbolical identity is processed (cfr. Martins 2006). While this understanding may well be a symbolic legitimation, in assuming that there is such a thing as 'lusophone culture and community', it also seems true that lusofonia implies a first line of defense, linked to various activities of the economic sector, "which first characteristic is the "firmness of Portuguese national will" (Dias 2009:6-7)".

Dias (ibid.) accordingly defines lusofonia as an "identity conundrum" - a conceptual context of contested discourses. She sees the concept not only as a description of a community of shared language and colonial history, but as a concept that invokes Portugal as a nation (with its identity and history as a country), as well as the imaginary that involves its global relations. Lusofonia can thus be characterized as a "neo-imperialistic project in its intentions and symbologies, pursuing a 'lusocentrical'/eurocentrical/linear understanding of history" (ibid.). In this sense, it may be understood as a hidden continuation of Freyre's luso-tropicalism (Freyre 2006 [1933]) - the underlying notion that the Portuguese colonial empire, "due to historical and cultural reasons, had an inclination towards adaptation and miscegenation" (Almeida 2008:np).

In short, lusofonia is a widespread but contested signifier. The concept's universality is questionable as it is shared collectively but varyingly by individuals and elite groups in the political, cultural, artistic, and academic realms in the (capitals of the) countries involved (cfr. Lopes 2008:sp). The fact that lusofonia is used in a decontextualized way, and in a plurality of situations, makes it "symbolically dangerous, as a producer of a multicultural imperialistic common national feeling" (Dias 2009:7).

A critique of lusofonia thus is quintessential, and should be understood as "a first step towards a renovation of Portuguese cultural and identity representation” (ibid.). As

The concept of lusofonia combines two linguistic elements that constitute the word: luso/fonia/. 'Luso' derives from 'Lusitano', the inhabitant of 'Lusitânia', the designation of the Roman province including approximately all of Portugal south of the Douro river and part of Spain (Extremadura and a part of the province of Salamanca); 'fonia' denotes a population that speaks a specific language. The use of the concept of lusofonia however implies a broader, more diversified meaning than the corresponding linguistic concept (cfr. Cristóvão 2005: 652 ; Ciancio 2009: 3 ). 
Dias points out regarding some curatorial art exhibitions including artists from Portugal, Brazil and/or lusophone Africa, it is this counter-discourse, and its interrelation with a critique of the idea of nation and history, that informs a critical approach to lusofonia. Several musical and cultural events in Lisbon spring to mind, such as Lisboa Mistura, ${ }^{17}$ Festival Imigrarte, ${ }^{18}$ Africa Festival ${ }^{19}$ and Africa Cont, ${ }^{20}$ as well as the programming in Casa da América Latina ${ }^{21}$ that - consciously or not - achieve a critical perspective, developing alternatives or oppositions to the official idea of lusofonia. These projects alternatively focus, for example, on Brazilian cultural autonomy abroad, on their 'Africanity', or on the general idea of 'interculturality' instead of ideas of 'Portugality'|'Portugueseness'। 'Portuguesofonia'.

The origins of this counter-discourse can possibly be exposed through Almeida's assumptions on what he calls 'PostLusotropicalism' (Almeida 2008: np). Almeida argues that both the Portuguese state and the population had their own representations of "colonial miscegenation, tolerance and exceptionalism" challenged by the flux of migrants from ex-colonies in Africa and then from Brazil that started to arrive in Lisbon in the late I980s (ibid.). Still according to Almeida, this resulted in a "covert racism", resulting from the "cognitive tension" between hegemonic discursive statements on the historically nonracist character of Portuguese society on the one hand, and the social, professional, legal and geographical exclusion of migrants, on the other (ibid.). This is in line with Manuela Ribeira Sanches' thoughts (2010: $\mathrm{np}$ ) about the integration of migrant populations from Portuguese-speaking African countries in the old colonial metropole: "[Blacks seem] to be accepted in Lisbon in order to market the city as part of a cosmopolitan global space, characterised by the juxtaposition of the exotic and the familiar [...]. Although seen as the result of the mixing of African origins with Brazilian sounds and transatlantic travels, the Atlantic still seems to resist the adjective of Black, in consonance with other narratives in Portuguese imperial histories" (ibid.).

It therefore seems fruitful to view lusofonia as an arena of struggle, with the critique of Portuguese domination as the central axis. Below, I will verify the implications of these thoughts through the analysis of migrant musicians from Portuguese-speaking countries in Lisbon, both from an historical and contemporary perspective. Particular focus will be given to the role of the PALOP.

\section{A historical perspective}

As may have become clear from the historical insights in part 2, the CPLP countries and their populations have many historical events and conditions in common, and they continue to be linked economically and politically. In practical terms, however, the shift

\footnotetext{
17 http://www.sonsdalusofonia.com/Projectos/LisboaMistura/tabid/II r/language/pt-PT/Default.aspx (Last consulted: October 6, 2012).

I8 http://lisboaintercultural.blogspot.com/2008/04/festival-imigrarte.html (Last consulted: October 6, 2012).

I9 http://www.oi.acidi.gov.pt/docs/Revista_7/Migracoes7p284p285.pdf (Last consulted: October 6, 2012).

20 http://www.africacont.org/ (Last consulted: October 6, 2012).

2I http://www.casamericalatina.pt/ (Last consulted: October 6, 2012).
} 
that occurred after 1975 was substantial: the country that for centuries had projected itself as a nation of expansion and emigration now received considerable immigration http:// lisboaintercultural.blogspot.com/2008/04/festival-imigrarte.html (Last consulted: October 6, 2012) flows from its former African colonies and - since the r 990 - from Brazil. For PALOP in particular this implied two simultaneous realities: the repatriation of the Portuguese former inhabitants of former colonies, mostly of European descent, and the arrival of immigrants of African nationality and ancestry. In short, the colonial trauma coincided with a reversal of migration patterns, as the increasing heterogeneity of the population forced Portuguese society to reflect on a number of issues related to immigration, while at the same time continuing to be a country of emigration (cfr. Maciel 2010: 213-4).

However, although the colonial subjects had been part of the representational frame of the (colonial) nation through a rhetoric of inclusion, they became a problem from the moment they were formally considered as peers: not only did the rapid decolonization process create reserved attitudes towards the peoples of the former colonies, but EU membership also called for a break with the past colonial ties - implying restrictive policies towards African and Brazilian immigrants. Thus, on the one hand, the reorientation towards Europe and democracy correlated with the delimitation and exclusion of the former colonies; while on the other hand, Portugal continued to be a the transatlantic country that tried to maintain an equal bond to its former peripheries. In fulfilling both roles, Portugal tended to assert itself as an intermediary between other Portuguesespeaking countries and Europe (also see ibid.:206, 235-36).

It is in this context that Lisbon formed itself into a modified Lusophone space: the significant immigrant populations from former colonies not only increased internal heterogeneity, but they also formed a 'missing link' that justified political commitment and the construction of 'special ties' with the Portuguese-speaking countries. Despite Portugal's official diversity discourse and its institutional immigrant reception framework - for which it received international acclaim -, racism, social exclusion and objection to further immigration were not erased from Portuguese society. The greatest distancing occurred more with regard to Africans than to Brazilians, even though in both cases the Portuguese language and a common past are shared (see below). Beyond the diversity discourse, the emphasis on the affirmation of socio-cultural contrasts of immigrants and ethnic minorities may also have been a subtle way of stating the superiority of the cultural values of the host society, thus legitimizing existing socio-cultural hierarchies (cfr. ibid.: 207, 209-10, 213-4, 229-230).

Since the ig6os, musicians from the PALOP and Portugal have increasingly performed together in Lisbon. For Portuguese nationals, this was especially manifest in the domain of 'música popular portuguesa'22 (Portuguese popular music), the 'canção de intervençã $0^{23}$ (protest song) and performers and composers with biographical links to the

\footnotetext{
22 Salwa Castelo-Branco and Rui Cidra (2010), 'música popular portuguesa', in Salwa Castelo-Branco (coord.), Enciclopédia da Música em Portugal no Século XX. / Encyclopedia of Music in Portugal in the XX Century. Círculo de Leitores / Temas e Debates, pp. $875-8$.

23 Maria de São José Côrte Real (2010), 'canção de intervenção', in Salwa Castelo-Branco (coord.), op. cit., pp. 220-8.
} 
PALOP, such as José Afonso (Angola and Mozambique), Fausto (Angola) and, later, João Afonso (Mozambique) (cfr. Cidra 2010: 196-7 and 773-4).

In the I 960 s, Lisbon on the one hand served as an intersection for the articulation of anti-colonial sentiments through music by migrants, be they intellectuals, musicians, students, athletes or activists. On the other hand, the alien context also stimulated original performance practices to represent new migrant identities. The contexts of performance and the musical aesthetics of these metropolitan migrants thus stood in opposition to Portuguese political discourse and practices that promoted the idea of 'Portugueseness' in controlling the colonial empire. This friction largely continued after the Portuguese revolution (1974) and the respective independencies of the PALOP (1975), causing massive migration movements towards Portugal involving both 'retornados' and Africans.

Migratory fluxes between countries with a shared language or history, such as former colonies and the corresponding metropoles, tend to be frequent in the world (Cristóvão 2005: 705). Beside Cape Verdeans (numerically predominant because of their historical migration tradition related to droughts on their islands), citizens of Angola, Guinea-Bissau and Mozambique also migrated to Portugal because of unstable political contexts and civil war in their home countries. From the I980s onwards, and increasing in the I 990 and 2000 , large scale Brazilian immigration further stimulated a lusophone perspective in Portugal.

From the ig6os onwards, the concept of lusofonia increasingly informed several music projects in Lisbon. Cape Verdians, the migrant community with most historical visibility, functioned as the protagonist of the PALOP in Lisbon. This is clear from the pioneering role of its resident migrant musicians such as Dany Silva, Tito Paris, Bana and Celina Pereira. The popular live music and dance venues B.Leza, ${ }^{24}$ and to a lesser extent Lontra, Bana and Ritz, were pivotal in cementing regular contacts between Portuguese-speaking African migrants in Lisbon. As pointed out by Cidra (2010:789), B. Leza utilized the concept of lusofonia in structuring its programming, presenting collaborations between Portuguese musicians and migrant musicians from Cape Verde, Angola, Guinea-Bissau and Mozambique, in front of a mixed European and African public. The Capeverdian musicians that - in different phases from the r970s and throughout the I990s - formed the nucleus of B. Leza, were fundamental in the development of PALOP migrant musics in Portugal. However, given the fact that most migrant musicians did not have access to Portuguese recording studios or publishing companies, this development largely occurred without an institutional or commercial framework of support. The musical activity of PALOP migrant musicians in Portugal thus remained restricted to live performances through social networks in discotheques with recorded music, in dance halls and in restaurants.

24 http://blogdibleza.blogspot.com (Last consulted: October 6, 2012). 
The delay in Portuguese recognition of their work would point these PALOP migrant musicians towards commercialization in other European capitals such as Paris, Amsterdam and Berlin. In fact, at the time of writing, most of these musicians still did not publish their music with Portuguese record labels. For example, Lura, Cesária Évora and Bonga record with Lusáfrica (Paris); Waldemar Bastos, Sara Tavares, Tito Paris and Mariza with World Connection (Amsterdam); Mayra Andrade with Sony Music France (Paris); and Celina Pereira with Piranha Music (Berlin). As pointed out by Cidra (2010: 789), this transnational discographic framework stimulated Portuguese recognition and visibility for PALOP migrant musicians, connecting Lisbon with other centers with diaspora groups from Angola, Cape Verde, Guinea-Bissau, Mozambique and São Tomé and Príncipe in Europe and the USA, as well as with the countries of origin.

Interestingly, the perspective of Brazilian migrant musicians in Lisbon has been markedly different from that of their PALOP colleagues. ${ }^{25}$ Historically speaking, relations between Portugal and Brazil have always been largely bi-directional, both in terms of migration and of expansion of radio, recordings and shows (Cidra 2010:178, 773-4, 782-3). The continued dissemination of a broad range of Brazilian music in Portugal, contrasts with the limited profile of Portuguese music [singular] in Brazil, and can be traced back to the discrepancy in the record industry climate of both countries. This resulted in the continuing dominance of Brazilian sounds, ideologically associated with the concept of lusofonia in Portugal.

At the same time as the musics of PALOP transnationally became part of the world music circuit (largely from other European capitals than Lisbon), the emerging concept of lusofonia became imbued with political and institutional meaning (cfr. Cidra 2010: 179). Under this increasing internationalization, political institutions and cultural initiators in Lisbon gradually became interested in promoting interaction between Portuguese musicians and their lusophone counterparts. Initially, these collaborations would especially include migrant musicians from PALOP living in Portugal, active in the areas of jazz and música popular portuguesa (ibid.). This is clear from Sons da Fala (1994) ${ }^{26}-\mathrm{a}$ festival in Galicia ${ }^{27}$ (Spain) that, in its first edition, featured 9 lusophone singers ${ }^{28}$ (and 9 accompanying musicians) born in the PALOP or Portugal, with numerous onstage collaborations - as well from Orquestra Sons da Lusofonia ${ }^{29}$ (1995), founded and directed by jazz saxophone player Carlos Martins in Lisbon. These associative actors intensified the dialogue between Portuguese musicians and PALOP migrant musicians, with shared

25 Please be referred to footnote 42 for a more detailed argumentation.

26 http://www.pflores.com/sonsdafala/index.php (Last consulted: October 6, 2012).

27 A border region in the northeast of Spain that is known for stimulating its linguistic ties and geographic proximity with Portugal. The region's language, Galician, is very similar to Portuguese and the region has various musicians and cultural associations that are present in Lisbon.

28 These singers were Sérgio Godinho, Vitorino and Janita Salomé (Portugal), Tito Paris (Cape Verde), Filipe Mukenga (Angola), André Cabaço (Mozambique), Guto Pires (Guinea-Bissau), Juka (São Tomé and Princípe) and Madeira Júnior (Brazil).

29 http://www.sonsdalusofonia.com/SonsdaLusofonia/tabid/58/language/pt-PT/Default.aspx (Last consulted: October 6, 2012). 
performances at a number of official occasions. However, it is noteworthy that Brazilian musicians did not figure in either of these projects.

Brazilian musical participation in projects evoking the notion of lusofonia would be stronger in Expo '98, which involved established Brazilian musicians on tour rather than resident migrant musicians from Lisbon. Expo ' 98 however would further encourage interest in PALOP migrant musicians originating from Lisbon.

Expo '98's linking theme 'The Oceans, a Heritage for the Future' discursively set out to reconnect the transcultural webs that resulted from 500 years of cross cultural interchange between Portugal and the regions with which it came in close contact in Africa, Asia and the Americas. As pointed out by Cidra (2010: 179), this "discursive allusion" to Portugal's maritime expansion as well as to the cultural marks it globally imprinted, thus resulted in programming that accorded with the "new political concept" of lusofonia, as a singular aspect of the internationalization of Portuguese culture (Santos 1999: 132-3). Effectively, all countries pertaining to the lusophone space were present, including CPLP, with a proper programming. This shows from the total number of 170 sessions at Expo ' 98 that were the responsibility of Portuguese-speaking countries and regions as well as CPLP (Brazil 6o, Angola 23, Mozambique 21, East Timor 19, Cape Verde I8, Macau Io, São Tomé and Príncipe 9, Guinea-Bissau 5, CPLP 5). The relative weight of initiatives by Portuguese-speaking countries and territories in the total of performances was between $14 \%$ and $17 \%$, varying according to categorization criteria (ibid.).

Musically, Brazil was the Portuguese-speaking country that was best represented at Expo '98. In addition to offering concerts by Brazilian musicians popular in Portugal (but not residing in Portugal), the event also featured collaborations with musicians from other Portuguese-speaking nations (which did involve local communities). The Expo's special project Sem Legendas $3^{30}$ challenged four internationally renowned musicians to create unprecedented collaborations, using lusofonia as a reference. This included Caetano Veloso (with Paulinho Vieira and Pedro Abrunhosa); Sadao Watanabe (with Toquinho, Ala dos Namorados and N'Goma Makamba), Cesária Evora (with Marisa Monte, Dulce Pontes and Finka Pé), and David Byrne (with Balanescu Quartet, Tom Zé and Waldemar Bastos). Other musicians from the PALOP (such as Lura, Bonga, Filipe Mukenga, Netos do N'Gumbé, General D, Simenter), and Portugal (António Chainho, Mísia, Madredeus, Né Ladeiras) and Brazil (Maria Bethânia, Chico César) also performed together (Santos 1999:92-4, Cidra 2010:178).

Expo ' 98 was hence a pioneering event that brought together different musicians from the lusophone world. ${ }^{31}$ Previously unseen collaborations between musicians from Portugal and other Portuguese-speaking countries were programmed, reuniting lusophone diaspora communities in Lisbon with performers from their country of origin. These musical collaborations not only emphasized the idea of lusofonia for an international audience, but also explicitly connected the concept to the city of Lisbon (Santos 1999: 92-4, II2-3; Cidra 2010: 789).

\footnotetext{
30 'Without subtitles'. This a telling name indicating the growing awareness of Portuguese as a world language. In my interpretation, this could be paraphrased as 'no need for subtitles, we have talents in our own language'.

3I In this article, I will use the word 'lusophone' as a synonym for 'Portuguese-speaking'.
} 
The music compilation Onda Sonora: Red Hot + Lisbon ${ }^{32}$ (1999), under the curatorship of David Byrne, can be seen as an extension of this idea. The phonogram pioneeringly presented original material by Portuguese musicians (Pedro Ayres Magalhães, Carlos Maria Trindade), musicians from the PALOP and their diasporas in Portugal (Mário Lúcio Sousa, Lura, Bonga, Filipe Mukenga, Netos de N'Gumbé, General D), as well as musicians from Brazil (Vinicius Cantuária and Moreno Veloso) and Goa (Ekvat). The record was also a breakthrough for PALOP musics on the world music market (Cidra 2010: 179). Additionally, the anthology A viagem dos sons (1998) was also released, featuring ethnographic recordings from different parts of the lusophone world. Although the concept of lusofonia is not explicitly mentioned, it does inform this collection.

Since Expo ' 98 , several festivals centering on the concept of lusofonia have been organized especially in Lisbon, but also in other Portuguese-speaking capitals or state capitals (especially in Brazil) and in specific regions (Galicia/Spain; Macau/China). Governmental institutions, voluntary associations and cultural entrepreneurs organized these large-scale events, promoting the idea of lusofonia explicitly. The influence of these festivals on public opinion has been considerable, given the attendance figures and the regularity with which such events are staged, thus constituting an audience that is acquainted with musics that are promoted as 'lusophone'. Some recent examples are the festivals 'Nossa Língua, Nossa Música' in 2010 in Brasília (organized by Centro Cultural Banco do Brasil) ${ }^{33}$; the 'Semana Cultural da CPLP' in Lisbon, since 2008; 34 the yearly editions of Cantos na Maré - Festival Internacional de Lusofonia in Galicia (Spain), since 2003; ${ }^{35}$ Festival Musidanças in Lisbon, since 200I; 'Festival Internacional de Hip Hop da Lusofonia' in Luanda (Angola), in $2011^{3^{36}}$ as well as Festival da Lusofonia in Macau (China), since $1998 .{ }^{37}$

\section{A contemporary ethnography}

Given the historical background regarding colonial and post-colonial population movements outlined above, one can say that the musical culture of Portugal is heterogeneous. Portuguese history is characterized by the confluence of cultures within Portuguese territory. Musical traditions from different locations have coexisted and interacted in Portugal since the I5th century and have contributed to shaping Portuguese musical identities (Castelo-Branco 1997: introduction). As pointed out by Castelo-Branco (ibid.: 40), we are not only dealing with 'Portuguese influence', but also with a confluence of cultures mediated by the Portuguese. Thus, the musical repercussions of a Portuguese presence cannot be examined independently from the power

http://www.redhot.org/projects/ondaindex.html (Last consulted: October 6, 2012).

33 http://www.overmundo.com.br/agenda/nossa-lingua-nossa-musica (Last consulted: October 6, 2012).

34 http://cplp.dynamicweb.pt/Default.aspx?ID=2215 (Last consulted: October 6, 2012).

35 http://www.cantosnamare.org (Last consulted: October 6, 2012).

36 http://www.portalangop.co.ao/motix/pt_pt/noticias/lazer-e-cultura/20I I/7/33/Primeiro-Festival-InternacionalHip-Hop-Lusofonia-adiado-para-Setembro,6ca5f6ro-57ab-4da4-9aff-cbee8d6oc878.html

(Last consulted: January 8, 2013).

http://iilp.wordpress.com/2012/10/03/15-o-festival-da-lusofonia-em-macau/ (Last consulted: October 6, 2012). 
structures that developed: one should also consider the dialectic between ideological hegemony and group identity.

My analysis of Lusofonia, a (r)evolução [Lusophony, the (r)evolution] (produced by Red Bull Music Academy, Portugal, 2006) ${ }^{38}$, which I carried out during my master thesis research, shows that this documentary ideologically embodies the idea of lusofonia. It constructs a narrative that suggests that lusophone sounds have evolved but still belong together. Equally, the documentary promotes musical hybrids and multiculturalism in order to revalorize a historical notion of lusofonia. In attempting to increase musicians' visibility and professional opportunities in Portugal, Lusofonia, a (r)evolução mostly shows established musicians in the context of the record industry. Meanwhile, musical dynamics and social transformations from underlying migratory contexts are largely omitted.

The research hypothesis of the master's thesis was that a representation of the concept of lusofonia in Lisbon could be further enriched by including resident migrant musicians from Portuguese-speaking countries that perform in the circuit of bars, restaurants and associations. To verify this hypothesis, extensive field research was carried out in Lisbon. The research field included collective performances announced through the media (such as modest festivals or paid performances); individual performances in restaurants and bars; and performances resulting from the initiative of voluntary associations or official institutions, mostly held in public spaces. Ethnographic interviews and participantobservation with selected migrant musicians from Portuguese-speaking countries were also conducted. Furthermore an interview guide was designed that included questions about lusofonia, language and music as well as the context of (lusophone) musics in Lisbon. Each interview began with open questions, only discussing concepts (such as lusofonia) or categories (such as lusophone musics) as the interview progressed and if these denominations were not emically used (by the interviewees).

Several criteria guided the selection of interviewees. A first criterion was nationality, given the transnational dimension of lusofonia, entailing different Portuguese-speaking countries from which many migrant musicians in Lisbon originate. Second, given the similarity of their discourse, certain musicians were grouped together - all singer-songwriters that have largely performed outside of the commercial circuit. Third, all interviewees are first generation musicians, maintaining strong (emotional and/or physical) connections with their home countries, and regard the music that they make as "tradition rooted in the nation" [my wording].

Thus, interviews with the following musicians were selected: Aldo Milá (Angola), Guto Pires (Guinea-Bissau), Jefferson Negreiros (Brazil), Tonecas (São Tomé and Príncipe), José Amaral (East Timor), Zézé Barbosa (Cape Verde) and Costa Neto (Mozambique). These contacts came about quite naturally, either through existing research at my hosting research institute or through cross-referencing by these musicians to one another. In this sense, the social network that is displayed here emerged organically. ${ }^{39}$

38 http://www.redbullmusicacademy.com/video-archive/documentaries/3 (Last consulted: October 6, 2012).

39 Due to the restricted dimensions of a Bologna master thesis, I eventually had to limit myself to one interviewee for each country. But during field research, I managed to interview 2 or 3 different musicians for each country. 
I also observed performances of these musicians in restaurants and bars in Lisbon: Aldo Milá in Irish Pub O'Gilins, Jefferson Negreiros with Dona Canô in Onda Jazz and with Banda Toque de Classe in Cuba Libre, José Amaral in Associação Solidariedade Imigrante (SOLIM), Tonecas in restaurant Sabor ao Brasil, Costa Neto in FNAC Colombo café, and Zézé Barbosa in Associação Caboverdiana Casa Mãe. ${ }^{40}$

My aim was to explore the ways in which these musicians conceptualized the notion of lusofonia. How does lusofonia affect their relationship to other local musicians, associations and institutions, and to their own creative undertakings?

The ethnography resulted into a relational understanding of what the concept of lusofonia means for resident migrant musicians from Portuguese-speaking African countries in Lisbon. It became clear that each of the interviewed musicians seeks to present the music they know of their own country, and that they do not identify themselves as 'lusophone musicians'. Lusofonia is a political term that currently seems to have little practical relevance for Lisbon-based musicians and their performance practice. The term does not yet affect their relationship to other musicians, to Portuguese or supra-national institutions, and to their own creative projects. Musicians referring to these do not use the term lusofonia. Furthermore, they regard the denomination 'lusophone musics' as problematic, as for them it involves issues of cultural and linguistic domination.

Specifically for PALOP musicians, the language connection problematizes a rigid definition of lusophone musics ('música lusófona'), a denomination that not all of them emically use. Aldo Milá points out that African languages and dialects are the "local cultural support, this means to the extent that language is practically an instrument of the specific cultural memory of these people." (Interview, 27/II and 4/12/2009). "The fact that Portuguese is a language of national unity on the level of public opinion doesn't mean that we have to omit all the aesthetic-cultural expressiveness in the languages of the respective people or their diverse ethnic groups," he reasons (ibid.) This assumption lies at the root of his critique of the term 'música lusófona': "What is this? Is it the music of the African countries that have Portuguese as an official language in combination with their local languages, or is it only the music of these countries sung in Portuguese? What I have verified in the former case, is that this side is experiencing difficulties," he says (ibid.).

Although not physically displayed here, all these interviews have informed my reasoning as well as my conclusions.

Before, since and after the time period in which my interviews took place, these musicians also performed at cultural events in Lisbon that either focus on Lusophone arts and culture (as is the case of Guto Pires and Tonecas at Festival Musidanças and at Bienal de Culturas Lusófonas, and Costa Neto at Festival Conexão Lusófona), African music (Costa Neto, Guto Pires at B.Leza), fusion and world music (Aldo Milá, Tonecas at Mercado do Fusão; Guto Pires and Tonecas at Festival TODOS - Caminhada de Culturas), and diversity (José Amaral at the event Música na Diversidade). Tonecas, Costa Neto and José Amaral have also played in Brazil on events either by CPLP or luso-brazilian chamber of commerce representations. The importance of the festival dimension is the focus of my ongoing PhD. 
Asked about the utility of Portuguese, most interviewees point to an identificational ambiguity: it is both the former oppressor's language and it is the language of revolution, independence and national unity. Costa Neto states that "this implies, in the first place, to assume Portuguese as a language that is also mine. It is part of our culture - Portuguese has existed more than 500 years in Mozambique. But I cannot say that I only speak Portuguese" (Interview, 10/12/2009). Portuguese is also the point of economic, political, social and cultural connection between the PALOP countries. Guto Pires thinks that "if we Africans would stop singing in Portuguese, there would no longer be 'música lusófona'. It could have grown more. But it did not grow as much as it should" (Interview, I8/I 2/2009).

Aldo Milá in this respect accuses the Portuguese media such as RDP/RTP África of promoting a derivative form of the latter. He argues that 'música lusófona' was created out of a stereotype that had been structured by some local radio specialists, an act which he considers to be "an abuse of confidence of African culture". In these broadcasts, " $80 \%$ is electronic music, with that electronic beat [imitates the rhythm knocking gently on the table], and sung in Portuguese. Africans however need to be integrated in their own country, with their own instruments, with their proper culture. I don't recognize myself in this [RDP/RTP] Africa" (Interview, 27/II and 4/12/2009).

These remarks seem to be in line with Sieber (2002) who, in the wake of the 1998 World Exhibition, conducted a similar ethnography on lusophone migrant musics in Lisbon. ${ }^{41}$ At the time, Sieber characterised the musical relationship between Portugal and its former colonies as a one-way street, entailing a tense interplay between persistent essentialist versions of 'Portugueseness' and emergent images of multiculturalism, fusion and hybridity. In other words: 'Portugueseness' contrasts with the influences from the ex-colonies on Portugal, of which visibility is being downplayed. In the same line of reasoning, 'Portuguese musics' allegedly do not take part in 'lusophone musics': the latter refer to the music of Portuguese-speaking communities outside of Portugal, or their representatives within Portugal, such as Portuguese-speaking African migrant musicians in Lisbon.

Interpreting the remarks of the musicians that I interviewed in 2008-2010, more than ten years after Sieber, it seems that little has changed. In fact, the interviewed PALOP musicians largely see their work as an urgent safeguarding and (re)valorization of 'African musics' (música africana). Costa Neto indicates that "it is more urgent to defend the traditional part of music, African music in this case, than doing what many are already doing. I'm saying: 'look, make use of me to value this world's heritage" (Interview, I0/12/2009). Guto Pires in this sense point to a bias towards African musics in Portugal: "Portugal automatically demands that [our] music would be part of that stream of musical whitening [branqueamento musical]. You have to pass through fado [.] An African has to whiten his music to make it here" (Interview, I8/12/2009). Pires is convinced that this does not happen to the same extent in neighboring countries.

4I Although I encountered Sieber's article only after finishing my master thesis, I include this work here as an historical point of reference to Lisbon's music scene at the time of Expo ' 98 . My purpose is to compare Sieber's findings with mine both synchronically and diachronically.. 
The treatment of Brazilian migrant musicians in Portugal seems to be markedly different to the alleged musical domination of PALOP musics signaled above. ${ }^{42}$

Brazilian musicians are thought to have a more intimate relationship with Portuguese musics, as indicated by Jefferson Negreiros: "Fado, bossa nova: so this is pure lusofonia. A [Portuguese] person listening to fado will easily perceive the bossa nova rhythm. And a Brazilian listening to fado will succeed in accepting it because it 'has' bossa nova" (Interview, 10/11/2009 and 4/2/2010). However, due to the popularity of certain Brazilian music styles, a number of Brazilian migrant musicians in Lisbon do or did have problems in getting their proper compositions across.

That being said, my research has also shown that Lisbon displays a daily, growing interaction between Portuguese-speaking musicians and musics, despite the recognition issues illustrated above. These musicians from Portuguese-speaking countries play together at informal jams, as special guests at each other's performances, in special projects inspired by lusofonia or at festivals in which cultural entrepreneurs are using the concept of lusofonia to promote musics from Portuguese-speaking countries. On the other hand, it seem to be especially migrant musicians from Portuguese-speaking African countries that consider themselves cultural agents that use music to promote their native cultural values and languages, by using Lisbon as a communicative space. In Costa Neto's words, "artists, particularly the musicians that I know better, often forget what their main function is: before being musicians, they are cultural agents" (Interview, 10/12/2009). At festivals, the desired effects of both cultural entrepreneurs and lusophone migrant musicians interact to varying degrees and in ways that escape quantification. But there is undeniably some tension between both.

All interviewees regard Lisbon as a contemporary point of encounter for migrant populations from Portuguese-speaking countries and its musicians. "Lisbon is the point of departure where all Portuguese-speaking musicians meet with one another. The city is the center, not of everything, but it is a place where one can succeed in little time in bringing together all musicians from Portuguese-speaking countries" (Interview with José Amaral, 5/r/2010).

This can be explained through a different conception of the historical relations between Brazil and Portugal, a different imperial context and early decolonization. In part due to the persistent success of Gilberto Freyre's work, Brazil is often portrayed as 'país irmão' [sister country], a successful result of the Portuguese 'soft' colonization. As stated elsewhere, Rio de Janeiro was the Portuguese capital between 1808 and $182 \mathrm{I}$. When Pedro I returned back to Portugal, his 15 year old son declared Brazilian independence (which was without bloodshed,), implying that the first leader of the new country was Portuguese. Immigration from Portugal has since continued, leading to many Luso-Brazilian chambers of commerce (due to Brazil's size and economic potential). Reversely, Brazilian migrant populations in Portugal are a relatively recent phenomenon, roughly since the 1990's. Brazilian telenovelas, such as Gabriela (1979, remake 2012) were pioneeringly popular in post-dictatorship Portugal, and continue to be exhibited on Portuguese private TV channels (SIC, TVi) as well as on Brazilian television stations that have an active base in Portugal (Globo, Record). Politically, the two countries have bilateral agreements, with easier access to citizen's rights and transfers of acquired social security. In 201 2-2013, finally, their bonds were exemplified by the musical and cultural celebrations of 'Ano do Brasil em Portugal' and 'Ano do Portugal no Brasil', with artists from Brazil traveling to Portugal and vice versa.

http://www.anobrasilportugal.com.br/brasil-portugal/, http://anodeportugalnobrasil.pt 
In general however, a lack of institutional recognition for the contribution of Portuguese-speaking migrant musicians to the expressive culture of Lisbon translates itself into a shortage of venues for performance, or more specifically, places in which to perform one's own compositions. In my view, this shortage may well influence the perspective of migrant musicians regarding the concept of lusofonia, which in their eyes becomes something merely theoretical and politicized. Surprisingly, most interviewees suggest that the term can be useful in uniting forces and in increasing visibility of the elements it combines. "Something is missing here: we are so [culturally] rich but are not being appreciated today. A lot of music can be heard, with good musicians, but I see that on the cultural level, CPLP still needs to do a lot. And as long as I will be here, I will fight for this" (Interview with José Amaral, 5/r/2010).

Interestingly, many if not all of the interviewees - especially those migrant musicians coming from PALOP - do see some future relevance in the concept of lusofonia. They appeal to supranational institutions such as CPLP and to national governments of both home and host countries, asking for structural support to promote or disseminate the expressive culture of Portuguese-speaking countries, and indicating that migrant musics from these countries should be considered part of Portugal's cultural history and patrimony.

Some interviewees even point at the importance of implementing (a notion of) lusofonia in cultural and civic education. Portugal may miss out if it does not embrace its historical ties, argues Costa Neto. "Note, who loses with all this? Above all, the Portuguese, which know less and less about their own history. The history of the countries that speak Portuguese is a part of the history of Portugal. In my opinion, Lisbon has the responsibility to present a little bit of everything that constitutes its own history" (Interview, 10/12/2009).

These critiques are in line with the arguments of various Portuguese academic authors, such as Manuela Ribeiro Sanches, Ernâni Rodriguez Lopes, Luís Madureira and Miguel Vale de Almeida, among others. As the latter indicates, there are still "hardly any counter-narratives, representations of the African influence or experience in Portugal. It is as if the Lusotropicalist narrative were about spreading Portuguese cultural products around the world but never about the return journey, about the African and other cultural products in Portugal" (Almeida 2008). Incorporating migrant music from Portuguesespeaking countries is hence required, in order to tell a new story of nation-building and nationalism in Portugal.43 Or as Almeida states: "the Portuguese State and Portuguese society are now faced for the first time with empire striking back" (ibid.).

It seems that for migrant associations, cultural entrepreneurs and/or musicians, participation in events under a variety of labels (such as lusofonia, interculturality, fusion, world music, diversity) may represent various things: e.g. cultural affirmation of the African, Brazilian or Asian presence in Lisbon, contributing to the idea of Portugal as a multicultural country, or perceiving how to build a Lusophone community. As has 
also been pointed out by Maciel (2010: 230-2), fusion practices appear to intersect here with the phenomenon of 'positive ethnicization'. "In a reflection on the lusotropicalist roots of the ideology of 'interculturalism' that now dominates the official Portuguese discourse, fusion draws attention to how segments of migrant populations take advantage of the celebrations of diversity and hybridization to renegotiate identities in the context of broader belonging to call it lusofonia" (ibid.). This does not negate the fact that, in this post-colonial metropolis, former hierarchical - social, cultural, economic and political - relations, including racist traits, may continue to co-exist (cfr. ibid.: 234). However, at the time of writing, more and more bottom-up initiatives that promote cultural crossfertilization are emerging, indicating that Portuguese society is not immune to these trends, and that dominant national narratives are gradually giving way to less essentialist perspectives (cfr. ibid.: 207).

\section{Conclusion}

How do Portuguese-speaking migrant musicians in Lisbon conceive their surrounding community, and how do they mobilize or question existing structures and resources (cfr. Maciel 2010: 245)? In what ways does the postcolonial cultural context in Lisbon differ from colonial ones? Who organizes lusofonia activities and why, and are the latter affected by the current economic crisis?

Dealing with music as a way of analyzing social connections in a post-colonial city where cultural and political entrepreneurs deploy the concept of lusofonia, I have sought to understand what role migrant musicians from Portuguese-speaking African countries (PALOP), as well as Brazil and East Timor, play in this context in Lisbon. By understanding lusofonia as an example of cultural governing that promotes a transnational community ${ }^{44}$, I have questioned the ways in which the concept is utilized to manage the identity of individuals and groups pertaining to this lusophone space. Through both a historical and contemporary analysis of the position of migrant musicians from Portuguese-speaking African countries in Portuguese society, I have tried to illustrate how the concept of lusofonia informs social practices, performances and cultural identities. Indeed, lusofonia's power relations inform cultural production, in the sense that discursive constructions of musical and cultural fields is used to have or exercise power.

The city of Lisbon constitutes the postcolonial point of convergence for my research ethnography. Historically speaking, the importance of the city in thinking about the nationstate, cultural formations and migration is undeniable. As Bohlman (2004: xxiii) explains, "it is not by historical accident that historians begin discussions of European history with the 'city-state' and end with the 'nation-state'". Indeed: the capital consolidates the nation; it provides the geographical conditions that invite an extensive cultural mix; and it supports the institutions central to the state yet requires the constant in-gathering of immigrants. Colonialism and imperial expansion were exported from Lisbon but got imported again in the form of postcolonial migrants and transnational alliances such as CPLP. 
I have attempted to understand these social dynamics and cultural transformations, using the ethnography of music performance as a methodological tool. Music can provide a means by which the pre-structured social space can be transformed or contested. Categorization, as a social process, informs musical experience, since social categories are "labels applied to expressive culture that are socially constructed through discourse" (Sparling 2008: 409). The understanding of cultural and musical categorization is hence essential to the interpretation of the concept of lusofonia and its uses.

The biographies of postcolonial migrants are important tools in building an urban ethnography, and constitute an alternative to the global culture concept in studying transnational cultural practices (cfr. Turino 2003: 52). The grounding of analysis in 'personhoods' is especially important when dealing with ideas, products and practices that are geographically diffuse (ibid.), such as is the case of migrant musicians from Portuguesespeaking countries in Portuguese society. Their performance is a profoundly discursive form of behavior, used to understand, criticize and even change the worlds in which the performers live. By means of ethnographic interviews and participant-observation, both individual agencies and larger socio-cultural discourses can be mapped out. In this way, analyzing the life stories of musicians can help to design or adjust cultural policies.

In general, my research has shown a lack of recognition of the contribution of migrant musicians from Portuguese-speaking African countries to the expressive culture of Lisbon, related to Portuguese preconceptions. There still seems to some postcolonial tension that manifests itself in the lack of cultural integration in Lisbon, as signaled by many of the interviewees. This can be exemplified by the dichotomy that has been raised between Portugal's national music, fado, and the musics of its former colonies, appropriated by the label lusofonia.

Beyond viewing the political concept of lusofonia as a representational non-category culture-wise, my research has hopefully contributed to a better understanding of the practice of its protagonists, to which the Lusophone community is perceived as a form of representation, physical and symbolic, of a collective with singular traits (in this case, linguistic affiliation and cross-fertilizations that shared historical experience made possible). As suggested by Maciel (ibid.: 307-310), this community is a product of democracy that combines bottom-up societal inputs with the participation opportunities created by political institutions. However, a variety of concepts, the inconsistency of implementation processes and ignorance of everyday practices that sustain lusofonia as the driving force of a collective have delayed a timely and feasible implementation of institutional responses, as has been pointed out by the musicians in the case study.

Nevertheless, it can also be said that that a lusophone community is now gradually emerging, despite the heavy connotation of an ideological past. As also indicated by Maciel (2010: VII, 207, 215-6, 227-230), there is a growing reality that operates in diverse expressions, whether in informal initiatives, or in trade or socio-cultural activities, beyond institutional actions, generating the renegotiation of belongings and stereotypes, while at the same time promoting the adoption of aperture values. On the level of festivals, for example, Portuguese musicians are increasingly performing together with local migrant musicians from Portuguese-speaking countries. 
Despite several existing counter-discourses regarding lusofonia, all interviewed musicians do see some future relevance in the concept. They appeal to both supranational institutions and national governments, asking for structural support in order to promote and disseminate all the expressive culture of Portuguese-speaking African countries, indicating that the migratory musics of these countries should be considered as an integral part of Portugal's cultural expression and heritage. Portugal's delay in actively recognizing its 'lusophone' heritage can be converted into a privileged position that implies incorporating and promoting (local and transnational) migrant musicians from Portuguesespeaking countries (and 'affectively empowering' the corresponding populations), using Lisbon as an historical and contemporary center of coordination.

At the time of writing, there seems to be a gradual opening up of a space for the affirmation of a community within the Lusophone old center and other spaces within the Lusophone world. This community internally references Africa (which is not defined solely according to racial criteria, but includes the 'retornados', increasingly visualizing the African presence in the city beyond the focus of exclusion and stigmatization. Externally, it may help to consolidate the image of Lisbon as a space of production and dissemination of lusofonia. In addition, governmental institutions, voluntary associations and cultural entrepreneurs are increasingly interested in financially supporting lusofonia events. If these trends continue, then the commercial opportunities and tourist appeal are bound to proliferate.

\section{References}

ACIDI, I.P. (2010). Music and Migration. Special issue of Revista Migrações. Guest editor Maria de São José Côrte-Real. http://www.oi.acidi.gov.pt/docs/Revista_7EN/Migracoes7_EN.pdf (Last consulted: October 6, 2012).

Almeida, Miguel Vale de. (2008). Portugal's Colonial Complex: From Colonial Lusotropicalism to Postcolonial Lusophony. Paper presented at the Queen's Postcolonial Research Forum, Queen's University, Belfast, April 28, 2008. http://site.miguelvaledealmeida.net/wp-content/uploads/portugals-colonial-complex.pdf (Last consulted: October 6, 2012).

(2004). An Earth-Colored Sea: Race, Culture, and the Politics of Identity in the Postcolonial Portuguese-Speaking World.' New York: Berghahn.

Arenas, Fernando (2011). Lusophone Africa. Beyond Indepence. Minneapolis: University of Minnesota Press. (2005). (Post)colonialism, Globalization, and Lusofonia or The 'Time-Space of the Portuguese-Speaking World. Institute of European Studies. Paper 050302. http://repositories.cdlib.org/ies/050302 (Last consulted: October 6, 2012).

Bohlman, Philip. V. (2004). The Music of European Nationalism. Santa Barbara, Denver and Oxford: ABCCLIO.

Cidra, Rui (2010). Various entries, in: Enciclopédia da Música em Portugal no Século XX. / Encyclopedia of Music in Portugal in the XX Century,' coord. Salwa Castelo-Branco. Lisbon: Círculo de Leitores / Temas e Debates. 4 vols.

Castelo-Branco, Salwa El-Shawan. (2008). A Categorização da Música em Portugal: Política, Discursos, Performance e Investigação. Etno-Folk 12: 13-29.

(ed.).(1997). Portugal e o mundo. O encontro de culturas na música / Portugal and the world. The encounter of cultures in music. Lisboa: Dom Quixote. 
Ciancio, Patrizia. (2009). A CPLP na Sociedade do Conhecimento in Revista Eletrônica de Gestão e Sociedade: [np], Belo Horizonte: CEPEAD/FACE/UFMG http://www.face.ufmg.br/revista/index.php gestaoesociedade/article/viewFile/557/540 (Last consulted: October 6, 2012).

Cristóvão, Fernando (20II). A lusofonia no meio de algumas contradições. Revista Letras com Vida 2. Centro de Literaturas e Culturas Lusófonas e Europeias (Clepul), Faculdade de Letras da Universidade de Lisboa. http://www.ciberduvidas.com/lusofonias.php (Last consulted: October 6, 2012).

Cristóvão, Fernando (dir. and coord.), Maria Adelina Amorim, Maria Lúcia G. \&Susana Brites Moita (2005). Dicionário Temático da Lusofonia. Lisboa, Luanda, Praia, Maputo: ACLUS Associação de Cultura Lusófona e Texto.

Dias, Inês Costa (2009). Curating Contemporary Art and the Critique to Lusophonie. Arquivos da Memória. Antropologia, Arte e Imagem 5-6. Lisboa: Centro de Estudos de Etnologia Portuguesa.

Freyre, Gilberto (2006) [1933]. Casa Grande e Senzala [The Masters and the Slaves]. 48th edition. São Paulo: Global editor.

Guilbault, Jocelyne (2007). Governing Sound. The Cultural Politics of Trinidad's Carnival Musics. Chicago Studies in Ethnomusicology. Chicago: University Of Chicago Press.

Grossberg, Lawrence (1992). We gotta get out of this place. Popular conservatism and postmodern culture. London and New York: Routledge.

Klimt, Andrea \& Stephen Lubkemann (2002). Argument Across the Portuguese-Speaking World: A Discursive Approach to Diaspora. Diaspora II: 145-62.

Lopes, Ernâni Rodriguez (2008). CPLP e Lusofonia: de conceito multicultural a vector portador de futuro. Paper presented at the colloquium 'CPLP e Lusofonia: de conceito multicultural a vector portador de futuro', 9/5/2008, UCP, Lisboa.

Maciel, Cármen (2010). A Comunidade lusófona and A produção cultural como pilar estruturante da comunidade. $O$ investimento na língua e na(s) literatura(s) em português, in: A Construção da Comunidade lusófona a partir do antigo centro. Micro-comunidades e práticas da lusofonia. PhD thesis. Mimeo. Lisbon: FCSH-UNL. 106-1 36 and $162-205$.

Madureira, Luís (2006). Is the Difference in Portuguese Colonialism the Difference in Lusophone postcolonialism? On Toward a Portuguese Postcolonialism. Ed. Anthony Soares. Bristol: HiPLA.

Margerido, Alfredo (2000). A Lusofonia e os Lusófonos: Novos Mitos Portugueses. Lisboa: Edições Universitárias Lusófonas.

Martins, Moisés de Lemos (2006). Lusofonia e Luso-tropicalismo. Equívocos e possibilidades de dois conceitos hiperidentitários. Visages d'Amérique Latine 3.

Middleton, Richard \& Peter Manuel (2001). Popular Music,' in: 'The New Grove Dictionary of Music and Musicians. London: Macmillan.

Migração e Políticas de Desenvolvimento no Quadro da CPLP. International seminar for the Forum Gulbenkian Imigração, held June 2006 in Lisbon. http://www.gulbenkian.pt/media/files/FTP_files/ pdfs/OIM2.pdf (Last consulted: October 6, 2012)

Moehn, Frederick J. (2011). 'New dialogues, old routes: Emergent collaborations between Brazilian and Angolan musicmakers.' Popular Music 30 (2): 175-90.

Monteiro, Tiago (2008). Quanto vale o fado? Capital cultural, distinção social, legitimação simbólica: proposta teórico-metodológica para a análise do consumo de música portuguesa no Brasil. Contemporanea - Revista de Comunicação e Cultura 6 (2).

http://www.portalseer.ufba.br/index.php/contemporaneaposcom/article/viewArticle/3534 (Last consulted: October 6, 2012)

Naro, N. P., R. Sansi-Roca, and D. H. Treece (eds.) (2007). Cultures of the Lusophone Black Atlantic. New York: Palgrave.

Pais, José Machado, Joaquim Pais de Brito \& Mário, Vieira de Carvalho (2005). Sonoridades Luso-Afro-Brasileiras. Lisboa: Imprensa de Ciências Sociais. 
São José Côrte Real, Maria de (2010). Canção de intervenção. In Enciclopédia da Música em Portugal no Século XX./ Encyclopedia of Music in Portugal in the XX Century, coord. Salwa Castelo-Branco. Lisbon: Círculo de Leitores / Temas e Debates. 4 vols.

Sanches, Manuela Ribeiro (2010). Drawing the lines, postcolonial Lisboa and other modern fortresses Europe. 13 May 2oro. http://www.buala.org/en/cidade/drawing-the-lines-postcolonial-lisboa-and-othermodern-fortresses-europe (Last consulted: October 6, 2012).

(2004). Where is the post-colonial in-betweenness, identity and Lusophonia in Transnational contexts. Center for Cultural Studies at UC Santa Cruz.

Santos, Boaventura de Sousa (2002). Between Prospero and Caliban: Colonialism, Postcolonialism, and InterIdentity. Luso-Brazilian Review 2: 9-43.

Santos, Maria de Lourdes Lima dos (coord.) \& António Firmino da Costa (coord.), Rui Telmo Gomes, Vanda Lourenço, Teresa Duarte Martinho, José Soares Neves e Idalina Conde (1999). Impactos Culturais da Expo' 98 . Lisbon: OAC Observatório das Actividades Culturais.

Santos, Octávio dos and Luís Ferreira Lopes. (2006). Os Novos Descobrimentos - Do Império à CPLP: Ensaios sobre História, Política, Economia e Cultura Lusófonas. Lisboa: Almedina.

Sieber, Tim (2002). Composing Lusophonia: Multiculturalism and National Identity in Lisbon's 1998 Musical Scene. Diaspora II (2): 163-88.

Sparling, Heather (2008). Categorically speaking: towards a theory of (musical) genre in Cape Breton Gaelic culture. Ethnomusicology, 52 (3): 401-25.

Stokes, Martin (2007). Musical Cosmopolitanism. http://digitalcommons.macalester.edu/cgi/viewcontent. cgi? article $=1002 \&$ context=intlrdtable (Last consulted: October 6, 2012).

Turino, Thomas (2003). 'Are We Global Yet? Globalist Discourse, Cultural Formations and the Study of Zimbabwean Popular Music.' British Journal of Ethnomusicology 12 (2): 51-79.

Vanspauwen, Bart (2010). The (R)evolution of Lusophone Musics in the City of Lisbon. MA Thesis. Mimeo. Lisboa: FCSH-UNL (Universidade Nova de Lisboa). 